\title{
On the Application of Flipped Classroom in Cultivating Liaoning Scientific Foreign Language Talents
}

\author{
Huanhuan $\operatorname{Ren}^{1, a^{*}}$, Chi Ma ${ }^{2, b}$ \\ ${ }^{1}$ Teaching and Research Institute of Foreign Languages, Bohai University, Jinzhou 121013, China \\ 2 Jinzhou Institute of Forestry Research, Jinzhou Forestry Bureau, Jinzhou 121013, China \\ arenhuanhuan2014@163.com, ${ }^{\mathrm{b}}$ machi2014@tom.com
}

Keywords: Flipped classroom; Scientific foreign language; Liaoning talents

\begin{abstract}
Flipped classroom is proved popular amongst the instructors across the globe and it is already being embraced to a certain extent by scholars in universities and schools. There are some truth in the idea that flipped classroom is applied and experimented in cultivating Liaoning scientific foreign language talents in China. Based on the discussion of origin of flipped classroom, wisdom behind flipped classroom and development of flipped classroom, the dynamics of the flipped classroom model is analyzed whilst teachers instructing scientific foreign language in Liaoning province. It could be argued that three main stages of flipped classroom in cultivating scientific foreign language talents should be given much emphasis to, which is the reflection on first exposure outside of school day, the construction of knowledge through classroom activities, and the engagement in scientific foreign language learning community. It's hoped that an engaging and productive flipped classroom is formed in combination with the actual teaching condition in China's scientific foreign language pedagogy.
\end{abstract}

\section{Introduction}

Flipped classroom is a relatively new concept which gained traction in the latter part of the last decade and it is already being embraced to a certain extent by scholars in universities and schools. There are some truth in the idea that flipped classroom is applied and experimented in cultivating Liaoning scientific foreign language talents in China. It's concurred that flipping the classroom means instructors completely re-think how to do the job they have done a certain way for years. In this thesis, we seek to argue for how to instruct scientific foreign language under the flipped classroom model and how to strive to form an engaging and productive flipped classroom in combination with the actual teaching condition in China's scientific foreign language teaching. This paper is a summary of this research work, which hopefully provides a useful reference for future flipped classroom in pedagogical practice.

\section{Introduction and Development of Flipped Classroom Teaching Mode}

Origin of Flipped Classroom Teaching Mode. Flipped classroom teaching mode is originated in the United States. Since Jonathan Bergman and Aaron Sams first experimented with the idea at Woodland Park High School in Woodland Park, Colorado in 2004, flipped learning has exploded onto the larger educational scene. Basically, it all started when Bergman and Sams first came across a technology that makes it easy to record PowerPoint presentations. They recorded and posted some of their high school chemistry lectures on YouTube for students who missed class, and they saw an opportunity to make sure that missing class didn't mean missing out on the lessons. As Aaron Sams and Jonathan Bergmann states in the book Flip Your Classroom: Reach Every Student in Every Class Every Day, "in this model of instruction, students watch recorded lectures for homework and complete their assignments, labs, and tests in class.[1]" That is, once students have the option of reviewing the lessons at home, the teachers realize the shift reserves additional class time for collaborative work and productive mastery exercises. It's concurred by the authors that the model is a 
mixture of direct instruction and constructivism [1]. With the idea of online lectures spreading, Bergman and Sams were asked to speak to teachers around the country of America about their methods. Little did they know that this clever adaptation of technology would contribute to one of the fastest-growing educational trends in the country: the flipped classroom.

Wisdom behind Flipped Classroom Teaching Mode. Flipped classroom inverts traditional teaching methods through delivering instruction online outside of class and moving homework into the classroom. Thus is there any proof that flipping the classroom actually works? What makes the flipped classroom such a groundbreaking idea? Perhaps education researcher Benjamin Bloom's famous "Bloom's taxonomy" can give us a lot of insights into it. According to Bloom's taxonomy, types of learning are classified into three hierarchical models [2]. In his hierarchical model for cognitive learning, he classifies more passive learning like gaining knowledge and comprehension as low-level cognitive work, while more engaged learning, like evaluation, application, and synthesis, requires high-level cognitive work. The promise behind flipped classroom is that students are doing the lower levels of cognitive work outside of class, and focusing on the higher forms of cognitive work in class, where they have the support of their peers and instructor [3]. As the scholars observes, the flipped classroom model takes a more intuitive approach to Bloom's taxonomy by providing students with a supportive classroom environment for them to tackle harder, higher level cognitive work, while letting them do the "easier" lower level cognitive work, like listening to a lecture, at home[4]. In brief, instructors who are flipping their class often feel the impact of this shift, with flipped classroom inverting traditional teaching methods through delivering instruction online outside of class and moving homework into the classroom.

Development of Flipped Classroom Teaching Mode. With the achievements of flipped classroom in education community, this new teaching mode has received close attention from education experts and scholars both at home and abroad. It's been one of the hottest topics in education for several years running and doesn't seem to be losing steam. Especially, recent advances in technology have unlocked entirely new possibilities for flipped classroom in most fields. New development pattern under the background of modern science and technology innovation may occur. Many scholars abroad including Jon Bergmann and Aaron Sams maintain a busy schedule of conferences, book-writing and blogging to promote the development of more refined flipped classroom models [5]. In 2011, Clintondale High School in Clinton Township, Michigan, adopted the flipped classroom model across all of its 9th-grade classes after completing an experiment in which half of classes flipped; at the end of the experiment period, the flipped students were achieving markedly better grades while the traditional students showed no change[6]. After seeing the popularity and success of the "flipped classroom" program at Clintondale, hundreds of schools across the country have adopted this model including, most recently, Massachusetts' Holyoke school district, which made headlines in August when it announced plans to adopt a "no homework" policy for the coming 2016-2017 school year[7]. However, in developing countries, it's still in its infancy, so more work is needed to be implemented in many places and at various directions. In sum, with technology constantly developing, there is no reason why flipped learning should not evolve alongside it.

\section{Dynamics of Flipped Classroom in Cultivating Liaoning Scientific Foreign Language Talents}

Flipped Classroom and Foreign Language Teaching. The flipped classroom approach has been used for years in some disciplines, notably within the humanities. The idea of moving toward a flipped classroom in cultivating Liaoning scientific foreign language talents is proposed in China, considering the complexity of scientific foreign language itself. Why to teach scientific foreign language? The quality of scientific foreign language teaching directly affects the overall development of ESP learning in China, and will also affect the connection of our scientific foreign language talents with international advanced transaction. However, It's observed that the traditional one-size-fits-all model of education often results in limited concept engagement and severe consequences [8]. The application of flipped classroom in scientific foreign language teaching practice may solve the flaws 
in traditional education method of scientific foreign language courses in colleges and provide new teaching concepts and ideas for language education classroom in China. It's about moving the more passive elements of learning outside of the classroom, so that more class time is available for interactive, hands-on learning activities. The flipped classroom model has been adopted at some of the top universities around the world and has been the subject of numerous studies and pilot programs, with promising results. The idea of cultivating scientific foreign language talents through flipped classroom is Liaoning is an attempt worth efforts and endeavors.

Principles of Flipped Classroom in Scientific Foreign Language Learning. For a better scientific foreign language learning, several principles are suggested whilst moving toward a flipped classroom. Firstly, flipped classroom allows for constructive opportunities for scientific foreign language learners. Students learn by incorporating understanding of the subject into their existing knowledge base, and instructors should take an active role rather than being passively taught[9]. It's believed that flipped classroom is to provide an environment where the anxiety students experience can be reduced through group learning and social interaction. What's more, flipped classroom advocates humanism philosophy whilst teachers cultivating Liaoning Scientific Foreign language talents. The increased interaction with students in the classroom will help teachers gain a clearer idea of the different learning styles of their students, so they can tailor their instruction to the needs of each one. The flipped classroom is about making connections with learners and differentiating instruction, and instructors would love to move towards a flipped classroom because it can truly individualize learning for students. As well, flipped classroom provides the opportunity for learners to be autonomous. Scientific foreign language can review what they need when they need to, and move at their own pace. It's found that the success of flipping learning model relies on students learning on their own and in their own direction.

\section{Application of Flipped Classroom in Cultivating Liaoning Scientific Foreign Language Talents}

The Reflection on First Exposure outside of School Day. Most people hear "flipped learning" and picture learners watching videos at home. However, flipped classroom doesn't have to be exclusively about videos. That is, the flipped classroom is not a synonym for online videos. As many teachers can tell you, not everyone learns best through a screen. And it's not good idea that students will end up sitting in front of a screen for hours every night as they watch the bulk of the required videos. Videos can be part of it or not part of it, and more things (e.g. podcasts, recorded PowerPoint, textbook, printed materials, etc.) should be considered in scientific foreign language instruction prior to class. If it's about the videos for class preparation, interactive elements (e.g. quizzes and links, etc.) should be added to test students' comprehension of what they've just seen and help learners access any additional materials the instructor want the learner to read or view. Students watch lectures at home at their own pace, communicating with peers and teachers via online discussions. And one of the hardest parts about flipping class outside classroom is making sure that students do the preparation necessary for productive class time. For learners to make better use of the first-exposure before class, students are required to produce work (e.g. writing, notes, problems, etc.). At the same, instructors should avoid students getting distracted over recreational obligations and private home life interfering. In a word, first exposure outside classroom is not simply about viewing videos, and it's about the gain and reflection of first-exposure learning through various preparation work so that students gain necessary knowledge about scientific foreign language prior to class.

The Construction of Knowledge through Classroom Activities. Activity learning is one of the key components in the flipped classroom model. Once students has the option of reviewing the lessons at home, flipped classroom opens up additional time in class for more productive, interactive activities than the lectures they'd been giving. As it's stated by scholars, it is the interaction and the meaningful learning activities that occur during the face-to-face time that is most important[1]. What kind of activities is suggested in scientific foreign language class? First, mini-lectures in response to student questions should be given to learners. Students can receive more instructional support in the 
classroom from the instructor. As good instruction requires that ideas be presented in a number of ways, mini-lectures should be persuasive and interesting through the use of multimedia technologies (e.g. audio, video, PPT, etc.). Keep in mind that working on problems in class is the top thing to do before moving to next stage of scientific foreign language instruction. What's more, class time was devoted to activities that encourage students to process and apply knowledge learned prior to class. Learners are required to use scientific foreign language in the form of written or oral work, so that scientific foreign language can be acquired through various practices. Communicative and hands-on activities tend to keep students' interest in classroom. And the students can receive productive feedback through the processing activities that occur during class, which reduces the need for the instructor to find out individual learning difficulties in summative assessment on the students' work. In sum, instructors guide students to actively and interactively clarify and apply the knowledge during class, so that better learning outcomes could be achieved in scientific foreign language learning process.

The Engagement in Scientific Foreign Language Learning Community. Part of the appeal of flipped classrooms is that extra time in learning provides more opportunities for collaboration amongst students. This increased interaction helps to create a learning community that encourages learners to build knowledge together inside and outside the classroom. On one hand, class time is spent doing interactive activities to illustrate language points and increase engagement among scientific foreign language learners. Scientific foreign language learners are then freed up to work one-on-one with their peers on the content they most need support with so that any gaps or misunderstandings around the content can be solved in teams and groups. That means scientific foreign language learners can tap into the content and lessons beyond those they've developed and students can seek out insights beyond those their own classmates have. On the other, learners can reach for each other for learning difficulties online outside of school day. If learners still have questions after reviewing their materials, they can ask for their peers with learning difficulties in scientific foreign language learning process. By going to a flipped classroom, learners start connecting and collaborating with their peers worldwide who are passionate about language learning. The flipped classroom approach guides students to deeper thinking and higher levels of application, and proposes challenges to one another outside of class on content. All in all, the flipped classroom model gives scientific foreign language learners more opportunities to work directly with their peers and help students toward deeper understanding in scientific foreign language learning process.

\section{Conclusion}

Flipped classroom is proved popular amongst the instructors across the globe. It's worthwhile to experiment with flipping classroom in scientific foreign language teaching in China. Based on the discussion of origin of flipped classroom, wisdom behind flipped classroom and development of flipped classroom, the dynamics of the flipped classroom model is analyzed whilst teachers instructing scientific foreign language in Liaoning Province of China. It could be argued that three stages of flipped classroom in cultivating Liaoning scientific foreign language talents should be given much emphasis, which are the reflection on first exposure outside of school day, the construction of knowledge through classroom activities, and the engagement in scientific foreign language learning community. It's hoped that an interactive and productive flipped classroom is formed in combination with the actual teaching condition in China's scientific foreign language pedagogy.

\section{Acknowledgements}

This work is part of the project of On Cultivating and Developing Liaoning Scientific Foreign Language Talents with View to Bourdieu' Theory. This research was supported by the fund of Liaoning Planning of Philosophy and Social Science (Project No. L16CYY001). 


\section{References}

[1] J. Bergmann, A. Sams, Flip Your Classroom: Reach Every Student in Every Class Every Day, Washington DC: International Society for Technology in Education, 2012.

[2] L. W. Anderson, D. R. Krathwohl, eds. A taxonomy for learning, teaching, and assessing: A revision of Bloom's taxonomy of educational objectives, Allyn and Bacon, 2001.

[3] A. H. Marcus, Flipping the Classroom: Teachers Turn "Homework" on its Head, Educational Technology, May 24, 2012.

[4] G. Jones, What Are Flipped Classrooms? Retrieved from information on http://www.edudemic.com/flipped-classrooms-2/, June 27, 2016.

[5] C. Brame, Flipping the classroom, Vanderbilt University Center for Teaching. Retrieved from http://cft.vanderbilt.edu/guides-sub-pages/flipping-the-classroom/, 2013.

[6] Clintondale High School, Flipped Learning Model Dramatically Improves Course Pass Rate for At-Risk Students (case study), Pearson Education, 2013.

[7] K. Zapata, This Struggleing School "Flipped" the Classroom - and Grades Have Never Been Better, retrieved from https://www.babble.com, 2016.

[8] F. Strayer. The Flipped Classroom: Turning the Traditional Classroom on its Head, Flipped Class Conference, 2011.

[9] A. King, From Sage on the Stage to Guide on the Side, College Teaching, v41, no1, 1993. 